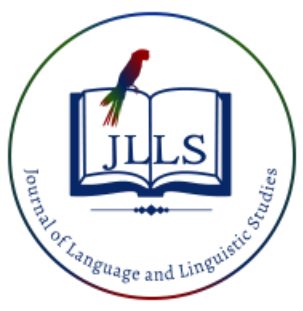

\title{
Teaching languages in a multicultural setting: Perspectives of a unique cohort of language teachers -at the Victorian School of Languages
}

\author{
Hayriye Avara $^{1 \text { a }}$ iD, Bruno Mascitelli ${ }^{\text {b }}$ iD, Catherine Bryant ${ }^{\text {c }}$ iD \\ ${ }^{a}$ Amasya University, Amasya, Turkey \\ ${ }^{b}$ Swinburne University, Melbourne, Australia \\ ${ }^{b}$ Department of Education Victoria, Australia
}

Avara,H., \&Mascitelli, B., Bryant, C. (2020). Teaching Languages in a Multicultural Setting: Perspectives of a Unique Cohort of Language Teachers - at the Victorian School of Languages, Journal of Language and Linguistic Studies, 16(3), 1480-1499.

Submission Date: 16/06/2020

Acceptance Date: 08/09/2020

\begin{abstract}
Within Australia, the State of Victoria has the greatest ethnic diversity and the largest number of second languages used at home. It also has the highest rates of students participating in language learning at school. It is also home to the country's largest and oldest government school for second language learning - the Victorian School of Languages (VSL) which teaches over 45 languages to approximately 16.000 students in 40 centres across the state. This paper develops a profile of the human capital of language teachers at the VSL and explores their views, which have until now been unexplored. It draws on an extensive anonymous survey of the VSL staff (mostly teachers) with over 552 responses. The results are both predictable and yet diverse. The findings show that the staff at the VSL are demographically a unique group, as they represent a rich gathering of cultural and linguistic diversity that is unlikely to be matched in any other institution in Australia. This paper presents the views of this exceptional cohort who work in a specialised environment that proudly holds the teaching of languages as its "core business". The survey revealed that staff are highly enthusiastic and strongly believe in the role that their school is playing in nurturing multilingualism and multiculturalism in the state of Victoria. But it also showed their deep concerns about a number of current problems in the field of languages education in Australia. It also revealed that there is currently a fragmentation of opinion on the best label for languages as a curriculum area. This paper argues that the considerations of the staff at this specialist institution are highly developed and can therefore be seen as a beacon for the concerns of professionals in the field of languages education in other educational settings in Australia and overseas.
\end{abstract}

(C) 2020 JLLS and the Authors - Published by JLLS.

Keywords: teaching; languages; Victorian School of Languages (VSL); Australia; multiculturalism; multilingualism

\footnotetext{
1 Corresponding author.

E-mail address: hayriyeavara@gmail.com
} 


\section{Introduction}

Within Australia, Victoria, according to the 2011 Census, is the jurisdiction most ethnically diverse and the State with the largest number of people born overseas and equally the State with the largest use of a second language at home (Australian Bureau of Statistics 2013). Equally, the State of Victoria is the jurisdiction with more students studying a language at school in Australia (Liddicoat et al. 2007, p. 34). Not surprisingly, Victoria is also home to a state specialist language school, possibly the most unique school for second language learning known as the Victorian School of Languages (VSL). The special nature of the VSL is in the way in which it acts as a complimentary school to the delivery of languages for the Education Department where existing schools are unable to offer these second languages. In 2011 the VSL offered 45 languages to 15,790 students in 40 centres via face-to-face classes on a Saturday morning, and distance education (DEECD, 2012a, p. 22). It had more than 900 teachers across a multiplicity of languages delivered both on city campuses as well as across regional locations throughout the State of Victoria. The VSL continues to provide a critical resource for language learning and remains what some have called the "lynchpin of Victoria's heritage language program" (Willoughby, 2006, p. 3). In addition, global language scholar Extra, posited the notion of a school model equally relevant to a European context because it has "...model-building significance for other multilingual immigrant societies" (cited in Clyne, 2005, p. 170).

This paper develops a profile of the language teachers at the VSL and seeks to explore their language teaching views, which have until study not received analytical attention. This paper and its analysis draw on an extensive anonymous survey of the VSL staff (mostly teachers) with over 552 responses that was conducted in late 2011. The results were both predictable and yet revealing. They showed that demographically, the VSL have a higher proportion of staff over 50 years of age and a much higher proportion of overseas born staff compared to language teachers in mainstream school settings in Victoria. As a group, they are responsible for delivering programs in 45 languages, thus representing a rich gathering of cultural and linguistic diversity that is unlikely to be matched in any other institution in Australia. In addition, the survey showed that the VSL staff are strongly supportive of the central role that the school is playing in fostering multilingualism and multiculturalism in the state of Victoria. This paper presents the views and opinions of this highly unique, specialised cohort who work in an environment that proudly holds the teaching of languages as its "core business". Therefore, their views are highly developed and very sensitive to current issues in language provision. Through the survey, staff expressed their deep concern about a number of problems that have emerged by virtue of decades of government neglect and inaction in the field of languages in Australia (Group of Eight, 2008, p. 1). These include Australian society's widespread indifference to language learning in general, and the consequent decline in student interest in language learning as demonstrated by declining enrolments. The survey of the staff also provided views on their interpretation of defining language terms and language studies as a curriculum area, and survey results suggest that the many shifts in terminology as a consequence of changing ideologies about languages over the decades has resulted in a fragmentation of opinion on the best definition for the languages area. This paper argues that the considerations of the staff at this specialist institution are highly developed and can therefore be seen as a beacon for the concerns of professionals in the field of languages education in other educational settings in Australia and overseas.

\subsection{Language use in Australia}

Australia, as a population has more than 270 separate ancestries, and especially since the end of the Second World has become a home to many different ethnic communities. In the 2006 Census, the ethnic ancestry profile recorded that the community was made up of Australian (37 per cent) and English (32 per cent) were the most commonly stated ones and other main ancestries stated were Irish ( 9 per cent), 
Scottish ( 8 per cent), Italian ( 4 per cent), German ( 4 per cent), and Chinese ( 3 per cent) (See Table 1$)$. The changes observed in the ancestry are parallel to immigration trends over the period, although the reason for some discrepancies have been attributed to differences in Census question design (ABS, 2006).

Table 1. Population, by self-reported ancestry (2001-2006)

\begin{tabular}{|c|c|c|c|c|}
\hline Ancestry & $\begin{array}{c}\mathbf{2 0 0 1} \\
' 000\end{array}$ & $\%$ & $\begin{array}{c}2006 \\
' 000\end{array}$ & $\%$ \\
\hline Australian & 6739.6 & 35.9 & 7371.8 & 37.1 \\
\hline Other Australian ancestries(a) & 106.4 & 0.6 & 129.9 & 0.7 \\
\hline New Zealander & 123.3 & 0.7 & 160.7 & 0.8 \\
\hline Maori & 73.0 & 0.4 & 92.9 & 0.5 \\
\hline Other Pacific Islander & 91.7 & 0.5 & 117.7 & 0.6 \\
\hline \multicolumn{5}{|l|}{ European } \\
\hline English & 6358.9 & 33.9 & 6283.6 & 31.6 \\
\hline Irish & 1919.7 & 10.2 & 1803.7 & 9.1 \\
\hline Scottish & 540.0 & 2.9 & 1501.2 & 7.6 \\
\hline Italian & 800.3 & 4.3 & 852.4 & 4.3 \\
\hline German & 742.2 & 4.0 & 811.5 & 4.1 \\
\hline Greek & 375.7 & 2.0 & 365.2 & 1.8 \\
\hline Dutch & 268.8 & 1.4 & 310.1 & 1.6 \\
\hline Maltese & 136.8 & 0.7 & 153.8 & 0.8 \\
\hline \multicolumn{5}{|l|}{ Middle Eastern } \\
\hline Lebanese & 162.2 & 0.9 & 181.8 & 0.9 \\
\hline Turkish & 54.6 & 0.3 & 59.4 & 0.3 \\
\hline Other Middle Eastern & 147.0 & 0.8 & 189.7 & 1.0 \\
\hline \multicolumn{5}{|l|}{ Asian } \\
\hline Chinese & 556.6 & 3.0 & 669.9 & 3.4 \\
\hline Indian & 156.6 & 0.8 & 234.7 & 1.2 \\
\hline Vietnamese & 156.6 & 0.8 & 173.7 & 0.9 \\
\hline Filipino & 129.8 & 0.7 & 160.4 & 0.8 \\
\hline Other Asian & 339.5 & 1.8 & 455.3 & 2.3 \\
\hline Other ancestry(b) & 243.9 & 1.3 & 386.4 & 1.9 \\
\hline Total population(c) & 18769.2 & 100.0 & 19855.3 & 100.0 \\
\hline
\end{tabular}

Source: ABS, 2006 Census of Population and Housing. (a) Includes Aboriginal, Torres Strait Islander and Australian of South Sea Islander descent; (b) Includes "mixed" ancestry; (c) Components may not add to totals because people may report more than one ancestry.

The cultural diversity of the Australian population has resulted in over 200 languages other than English being spoken. Among those languages, there are also more than 60 different languages spoken by Aboriginal and Torres Strait Islander Australians. The 2006 Census of Population and Housing found that 3.1 million people (16 per cent of the population) spoke a language other than English at home, (see Table 2), with an increase of 285,000 people or 10 per cent since 2001. In the State of Victoria however, this figure was much higher, with as many as 25 per cent of Victorian residents speaking another language at home. In addition, over 55,000 people spoke an Australian Indigenous language at home (ABS, 2006).

The extent to which these languages are spoken are reflected in the immigration policies over the last 60 years. At the end of World War Two, while the number of settler arrivals from countries such as Italy and Greece was high, the 1970s and 1980s saw large numbers from Lebanon and Vietnam, and the 1990s saw large numbers of settler arrivals from China. 
In 2006, the six most commonly spoken languages other than English were Italian, Greek, Arabic, Cantonese, Mandarin and Vietnamese, and speakers of these languages comprised 7 per cent of the total population (see Table 2). Greek, Arabic and Italian speakers had the largest proportions of Australianborn speakers, reflecting the fact that these languages were mainly brought to Australia more than 20 years ago and have been maintained among the children of those migrants. Languages spoken by migrants arriving in Australia more recently, such as Mandarin and Filipino, had a smaller proportion of Australianborn speakers (ABS, 2006).

Table 2. Persons Who Speak a Language Other Than English At Home, by language spoken - 2006

\begin{tabular}{|c|c|c|c|c|c|}
\hline & $\begin{array}{l}\text { Males } \\
(' 000)\end{array}$ & $\begin{array}{c}\text { Females } \\
(' 000)\end{array}$ & $\begin{array}{c}\text { Persons } \\
(' 000)\end{array}$ & $\begin{array}{c}\text { Proportion } \\
\text { born in } \\
\text { Australia }(\%)\end{array}$ & $\begin{array}{l}\text { Persons as a } \\
\text { percentage of } \\
\text { pop. }\end{array}$ \\
\hline Italian & 154.0 & 162.9 & 316.9 & 42.1 & 1.6 \\
\hline Greek & 124.3 & 128.0 & 252.2 & 52.8 & 1.3 \\
\hline Arabic & 125.0 & 118.7 & 243.7 & 42.9 & 1.2 \\
\hline Cantonese & 115.7 & 128.8 & 244.6 & 21.4 & 1.2 \\
\hline Mandarin & 103.3 & 117.3 & 220.6 & 12.6 & 1.1 \\
\hline Vietnamese & 94.3 & 100.5 & 194.9 & 30.3 & 1.0 \\
\hline Spanish & 46.6 & 51.4 & 98.0 & 24.4 & 0.5 \\
\hline $\begin{array}{l}\text { Tagalog } \\
\text { (Filipino) }\end{array}$ & 36.3 & 56.1 & 92.3 & 15.0 & 0.5 \\
\hline German & 34.7 & 40.9 & 75.6 & 19.9 & 0.4 \\
\hline Hindi & 36.4 & 33.6 & 70.0 & 13.7 & 0.4 \\
\hline Macedonian & 34.0 & 33.8 & 67.8 & 40.1 & 0.3 \\
\hline Croatian & 31.3 & 32.3 & 63.6 & 34.1 & 0.3 \\
\hline $\begin{array}{l}\text { Australian } \\
\text { Indigenous } \\
\text { languages }\end{array}$ & 27.1 & 28.6 & 55.7 & 96.4 & 0.3 \\
\hline Turkish & 27.1 & 26.8 & 53.9 & 42.3 & 0.3 \\
\hline Polish & 23.8 & 29.6 & 53.4 & 21.1 & 0.3 \\
\hline Serbian & 26.2 & 26.4 & 52.5 & 24.4 & 0.3 \\
\hline Maltese & 17.8 & 18.7 & 36.5 & 26.5 & 0.2 \\
\hline Netherlandic & 16.2 & 19.9 & 36.2 & 14.4 & 0.2 \\
\hline $\begin{array}{l}\text { All other } \\
\text { languages(b) }\end{array}$ & 424.8 & 448.2 & 873.1 & 18.5 & 4.4 \\
\hline Total & 1499.0 & 1602.5 & 3101.5 & 28.8 & 15.6 \\
\hline
\end{tabular}

Source: ABS, 2006 Census of Population and Housing. a)Persons whose birthplace was not stated, inadequately described, n.e.c. or at sea were excluded prior to the calculation of percentages; (b) Excludes languages that were not stated, inadequately described, and non-verbal so described.

English proficiency levels among people who spoke a language other than English at home varied with the age of the speaker and whether they were born in Australia (see Table 3). Around 84 per cent of all people aged under 25 years who spoke a language other than English at home spoke English well or very well, compared with 60 per cent of those aged 65 years and over. In terms of English spoken at home, 87 per cent of those born in Australia spoke English well or very well, compared with 81 per cent of the total population (Year Book Australia, 2008).

Table 3. Persons Who Speak a Language Other Than English At Home, by proficiency in English - 2006 


\begin{tabular}{|l|c|c|c|c|c|c|}
\hline & \multicolumn{6}{|c|}{ Age group (years) } \\
\hline $\begin{array}{l}\text { Total population } \\
\text { speaking other than } \\
\text { English at home }\end{array}$ & & $\mathbf{0 - 2 4}$ & $\mathbf{2 5 - 4 4}$ & $\mathbf{4 5 - 6 4}$ & $\begin{array}{c}\mathbf{6 5} \text { and } \\
\text { over }\end{array}$ & Total \\
\hline $\begin{array}{l}\text { Speaks English well or } \\
\text { very well }\end{array}$ & $\%$ & 83.6 & 88.2 & 78.5 & 60.3 & 80.8 \\
\hline $\begin{array}{l}\text { Does not speak } \\
\text { English well }\end{array}$ & $\%$ & 8.7 & 9.6 & 18.0 & 29.2 & 14.0 \\
\hline $\begin{array}{l}\text { Does not speak } \\
\text { English at all }\end{array}$ & $\%$ & 4.3 & 1.1 & 2.5 & 9.2 & 3.5 \\
\hline Total persons(a) & 000 & 963.4 & 1008.3 & 753.6 & 421.0 & 3146.2 \\
\hline $\begin{array}{l}\text { Australian-born } \\
\text { population speaking } \\
\text { other than English at } \\
\text { home }\end{array}$ & & & & & & 86.5 \\
\hline $\begin{array}{l}\text { Speaks English well or } \\
\text { very well }\end{array}$ & $\%$ & 81.2 & 96.2 & 93.5 & 82.8 & 8.5 \\
\hline $\begin{array}{l}\text { Does not speak } \\
\text { English well }\end{array}$ & $\%$ & 8.4 & 1.9 & 3.6 & 9.5 & 6.1 \\
\hline $\begin{array}{l}\text { Does not speak } \\
\text { English at all }\end{array}$ & $\%$ & 6.0 & 0.5 & 1.0 & 3.6 & 4.0 \\
\hline Total persons(b) & '000 & 554.0 & 259.1 & 72.8 & 12.4 & 898.4 \\
\hline
\end{tabular}

Source: ABS, 2006 Census of Population and Housing.

\subsection{Background}

Multilinguism has been a frequent practice in Australian society and not just in the last decades. There was ethno-linguistic diversity from the early days of European settlement. During the past 200 years, there were times when multilingualism was recognised and practiced and others when it was side-lined and discouraged. Therefore, there has been a periodic tension between monolingualism and multilingualism in Australia over time (Clyne, 1991). This tension has been a theme of debate between scholars over many decades. Clyne, for instance, refers to such a discussion by Bostock. He writes:

According to one scholar (Bostock, 1973) Australian governments have directed their policies towards achieving monolingualism. And yet Australia has an ethnolinguistic mix probably unparalleled in any other nation. It now has a more comprehensive and positive National Policy on Languages than any comparable country. This paradox is characteristic of a tension that has existed, throughout the history of white settlement in Australia, between three symbolic relationships of language and society: English monolingualism as a symbol of a British tradition; English monolingualism as a marker of Australia's independent national identity; and multilingualism as both social reality and part of the ideology of a multicultural and outreaching Australian society. This tension predates the federation of six British colonies into an Australian nation in 1901, and has not yet been resolved (Clyne, 1991, p. 1-2).

This multilingual approach and reality changed with the onset of the 20th century. Under pressure from jingoistic patriotism pushed during the First and Second World Wars, Australia's previous openness towards languages changed significantly. It required the cultural political change of the 1970s to reestablish a multiculturalist approach which allowed Australia to appreciate its more than 270 ethnic communities that spoke more than 200 languages. Multiculturalism in the early 1970s, especially in the field of education, enabled ethnic communities to re-acquire access to their language and not feel guilty in doing so.

Alongside the social benefits that migrant children might gain by maintaining their community language, many of the ethnic communities were given the opportunity to learn and retain their language 
and culture both in mainstream State schools when possible, or in afterhours schools (particularly in Saturday Schools) and also in private independent schools.

Carsaniga discusses the monolingual perception of multilingualism as an "obnoxious policy invented by a few 'lefties' in the early seventies"; however, he says "[i]n fact, multiculturalism and its complementary aspect, multilingualism, are the normal, natural condition of the most human societies, independent of 'culture' in the academic sense" (Carsaniga, 1994, p. 4). Languages stand in the centre of many initiatives to support and promote multicultural recognition. To Smolicz, the Australian example is a special one and he says, the "special feature of the Australian overarching framework is that it includes English as a shared language for all people and but not to the exclusion of other languages that are spoken in the community" (Smolicz, 1997, s.171).

\subsubsection{The teaching of Languages in Australia}

Australia has a rich history of teaching languages especially at primary and secondary school levels with every child receiving at least some instruction in languages. As mentioned in one study, "Australian schools, and particularly those in Victoria, have been praised internationally for their commitment to teaching a wide range of migrant languages through the state school system" (cited in Willoughby, 2006, p. 3). This development is part of a comprehensive plan to develop multicultural education which aims to promote diversity in education. In terms of external forces that affect language maintenance, the advent of explicit policies of multiculturalism in Australia in the mid-1970s and onwards had a great impact on language maintenance for migrants. This allowed them to maintain their own language, identity and other cultural traits, while still taking part in the general life of the nation.

According to one study (Willoughby, 2006) Victoria in Australia was considered ahead of much of Europe in language provision when the variety of the languages offered and the length of the time they have been available are considered. However, Willoughby continues, the system is not without its problems. She writes:

Most notably, Victorian students are largely disinterested in LOTE learning in senior high school, with only 13.5 per cent of students taking Year 12 LOTE in 2003. Victoria does not collect figures on the number of background speakers, as opposed to foreign language learners, who study LOTEs at secondary level. However, ACMA research from the mid-1980s found that only 1 in 8 background speakers were studying their heritage language at school...it remains a weak point of our heritage language programs that comparatively few students continue on to VCE level, and a number of languages also experience difficulty attracting students in the lower school years (Willoughby, 2006, p. 3).

Another challenge faced by the teaching of languages in Australia is the lack of financial support offered by the Federal Government. After a prosperous period in the 1970s and 1980s, the federal government made the decision to reduce the language funding, due to an inclination to focus on economic rationalism, as noted in the Lo Bianco report:

...during the late 1980s economic rationalism began to dominate policy discourse, with the result that government programs that were thought to give a poor economic return on their funding investment came under scrutiny. For language programs this approach resulted in cuts to funding for heritage language teaching, with policy increasingly stressing the need to limit federal funding of language programs to specific languages felt to be important for the purposes and trade (cited in Willoughby, 2006, p. 5).

Furthermore, there is the additional struggle to recruit qualified teachers for language delivery. To meet the demand in language teaching, the number of "overseas born and educated non-native speakers of English graduating from teacher education courses continues to increase" (Santoro, Reid \& Kamler, 
2001, p. 63). Equally stating the point Kearney observes talks to Leal's study, "In all States and Territories, the supply of language teachers is regularly seen as insufficient for current and emerging needs" (cited in Kearney, 1999, p. 11). Moreover, Kearney continues, "and many teachers are poorly trained" adding Quinn's advice in the Senate Standing Committee in 1984: “...[his] impression [was] that less than 50 per cent of teachers in secondary schools are competent in the language they teach, and again, less than half would be competent in up-to-date [teaching methods]" (Kearney, 1999, p. 11).

Multicultural education was strongly supported and took the form of ethnic language schools and institutes; community languages taught in mainstream schools and universities and other initiatives including ethnic festivals (Leuner, 2010, p. 28). During the mid-1970s the government multicultural policy also enabled multicultural media to flourish (SBS Radio, SBS Television, and ethnic press) and ethnic organisations received support from the Australian Government for maintenance of the diverse cultures. As explained by one scholar, SBS which broadcasts in 68 languages "is a vehicle for stories that would never be told, a version of Australia that would never be seen" and adds that "Diversity or 'foreignness' was presented as unpronounceable, unpalatable or incomprehensible in the Australian media landscape" (Brown, 2008, p. 1). To complement the ethnic media presence alongside radio and television there are also community newspapers that are published in their own language.

To many scholars, the benefits of learning languages are various: educational, intellectual, personal, social and cultural. As explained by Crawford, one of the goals of the Australian Language and Literacy Policy of "a language for all" is that it "reflects [the] growing awareness that monolingual Australians are disadvantaged and should be given the opportunity to broaden their cross-cultural understanding through learning another language " (Crawford, 1995, s.20).

\subsubsection{Providers of languages education in Australia}

Language education in Australia has three types of providers. The first is mainstream day schools, whether they are from the Government, Catholic or Independently sector. The second is the community schools that are run out of hours and are commonly known as "ethnic schools" or "community schools" (Clyne and Fernandez, 2008, p. 169). In the North American context, these are known as "heritage language schools". In the United Kingdom, they were previously known as "supplementary schools", and are now known as "complementary schools" (Creese, 2009, p. 267). The third type of provider in Australia is the state specialist language school, which is a government school that operates on an out of hours basis (Clyne and Fernandez, 2008, p. 169). These are also known as government-run specialist language schools (Lo Bianco and Slaughter, 1990, p. 53) as well as simply Schools of Languages (Liddicoat et al. 2007, p. 95).

\subsubsection{State specialist language schools}

State specialist language schools are government run schools that complement the language teaching in mainstream schools but do by providing after hours and distance education programs to primary and secondary students who do not have access to the study of the language of their choice in their day school. Presently, there are five government run language schools in Australia (Liddicoat et al. 2007, p. 95). Even though they are government run, and offer students alternative pathways for language study, each school functions slightly differently. They therefore represent "...a diverse collection of languages providers" (Liddicoat et al. 2007, p. 97). The state specialist language schools operate primarily on Saturday mornings but in some cases the classes are held on weekday afternoons as well. For many, but not all students enrolled at state specialist language schools, the language they learn is one in which they have a home background (Clyne, 2011, p. 178). These schools offer "...impressive participation and provision" (Lo Bianco and Slaughter, 1990, p. 53) in terms of the numbers of languages that are offered and the number of student enrolments. These schools are significant because they are "centers of expertise" (Extra, 2007, p. 201), have provided a framework for multilingualism, and have "mainstreamed 
community languages" (Clyne, 2011, p. 178) in Australia. Furthermore, the fact that these schools are not ethnospecific goes some way towards acknowledgement of “... language learning and maintenance as an important Australian activity" (Clyne, 2006, p. 115).

\subsubsection{The VSL}

The Victorian School of Languages is the largest and oldest of the state specialist language schools in Australia and not insignificantly its interstate counterparts offer fewer languages to smaller numbers of students (Lo Bianco and Slaughter, 1990, p. 53). Other states in Australia sought to adopt the VSL as a model for their own State when they established similar language schools (Ozolins, 1993, p. 30). The VSL's fragile beginnings as a "special experiment" on the margins of the Victorian state education system in fact date as far back as 1935. It was originally established as a small, isolated initiative by a senior Education functionary, John Seitz, the Chief Inspector of Secondary Schools (Mascitelli and Merlino, 2011, p. 41-42). In its 78 years of operation, the VSL has grown and developed significantly. In 2011, the VSL offered 45 languages to 15,790 students in 40 centres via face-to-face classes and distance education (DEECD, 2012a, p. 22). It is to this day considered the "lynchpin of Victoria's heritage language program" (Willoughby, 2006, p. 3). Overseas scholars have also recognised the VSL as a model to be emulated internationally. Extra states that the VSL is relevant to the European context because it offers "...modelbuilding significance for other multilingual immigrant societies" (Clyne, 2005, p. 170).

\section{Method}

In the conduct of this study, an anonymous questionnaire/ survey method was utilised to collect data from the respondents' demographic characteristics and their attitudes. The survey was conducted with the support and promotion of the VSL management and was the first survey of its kind to be undertaken among the VSL community. Out of about 800 VSL staff members, a total of 552 undertook the survey. Participants included VSL staff members with a range of responsibilities including teachers, assistant teachers, Area Managers, coordinators, school council members, as well as administrative staff. Survey participants included staff working at the VSL head office as well as those working in 40 VSL centres around Victoria. The online survey was made available to all VSL staff. The valid response rate was between 460 and 552.

The survey consisted of 46 multiple choice questions and a comments section at the end of the survey. It gathered information on respondents' demographic characteristics such as their language biography and their VSL work history, alongside their views on issues such as multiculturalism, multilingualism, languages, the Draft Shape of the Australian National Curriculum for Languages, as well as the role of the VSL in language provision.

\subsection{The Survey sections}

The survey consisted of six sections. The first section was titled "Demographic profile of the survey respondents" which offered 10 questions related to respondents' personal information, including gender, age, the length of their stay in Australia, the number of languages spoken, country of birth, educational qualifications, ethnic self - identity, their role at the VSL and the length of their association with the VSL.

The second section covered topics about Multiculturalism in Victoria, with six questions inquiring about respondents' views about ethnic community organisations, the maintenance of ethnic identities, monocultural expectations and the sensitivity to cultural diversity of teacher education programs offered in Victoria. 
The third section was called Multilingualism in Victoria Australia, and consisted of six questions that focused on respondents' views on "Victoria as a multicultural society", languages provoking controversy, emphasis on a monolingual society, Department of Education allowance of multilingual abilities, and the match between the needs of the communities and access to appropriate language programs.

In the fourth section, respondents were prompted to share their views on the future of languages. They were asked 18 questions ranging from the definition of an appropriate term for non - English languages in Australia, to their opinions about the coordination, planning, and promotion of languages delivery. In addition, respondents were asked if they agreed with the statement that "Victoria is better than the rest of Australia in encouraging language learning". They were also asked what they thought about those languages with low enrolments at risk of discontinuation. This section also included questions about the levels of awareness among schools and the wider community about the benefits of learning languages. They were also asked why they believe students choose to study a language, their views about students' loss of interest in language study, and the difficulty of finding qualified staff for language teaching.

In the fifth section, respondents were asked questions in relation to the role of the VSL in the provision of languages. They were asked about the school's strengths, and also about areas for improvement. Respondents were also asked to share their views on the failure of initiatives that link language learning to vocational skills, as well as lack of support from universities in language education. Moreover, they shared their opinions about the future of languages and what they thought about several points in the Draft Shape Paper of Australian Curriculum for Languages.

In the sixth section, respondents were given space to make their own comments through open-ended commentary, on the future of languages and the role of the VSL in language provision. This section resulted in a total of 236 comments, on a wide range topics, a selection of which is included below.

Due to limitations of space, the issues presented here represent only a selection of the sections explored in the survey. This paper concentrates on the findings about the staff of the VSL themselves, such as their demographic profile as well as some of their concerns about current issues in language provision, such a general indifference towards languages education and student motivation for language learning. The paper also describes the opinion that VSL staff have about the most suitable name for languages as a curriculum area.

\section{Results}

\subsection{Staff demographics at the VSL}

The Demographics section of the survey revealed that the staff at the VSL are a unique and highly specialised group. $86.5 \%$ of participants indicated that their role at the VSL was as a classroom teacher. In terms of the gender ratio, $79.1 \%$ of respondents indicated that they were female. This figure is a higher gender ratio than that found in teachers working across all sectors and all fields in mainstream schools in Victoria in 2011, which was 70.5\% (DEECD, 2012b, p. 16). This discrepancy can be attributed to the fact that the VSL is a specialised school that teaches only languages. One survey of language teachers in Victorian government schools revealed that in 2011, 81.6\% of languages teachers were female. In this respect, these figures confirm that VSL's gender ratio among its teachers is approximately consistent with language teaching workforce across the state in the government school sector.

The age demographics of the VSL staff, however, reveal a different picture. $45.1 \%$ of respondents indicated that they were aged 51 and over. This was by far the largest age group, with $30.9 \%$ of respondents indicating that they were in the next largest age group of 41-50 years old. These figures contrast with the teaching workforce across all fields in government schools in Victoria. It is estimated 
that in 2011, only $37.4 \%$ of all teachers working in Victorian government schools were aged above 50 (DEECD, 2012b, p. 16). When considering just the specialised group of LOTE teachers in Australia, the 50 and over age group appears slightly smaller again. It has been estimated that in $2010,18 \%$ of primary LOTE teachers and $35.9 \%$ of secondary LOTE teachers were 51 years old and above (Weldon, Rowley, \& McKenzie, 2011, p. 63).

These survey figures suggest that there is a significantly higher proportion of teachers aged over 50 working at the VSL than there is among the broader population of LOTE teachers working in mainstream settings in Australia. It is not clear why the VSL teaching population appears to consist of a larger proportion of teachers over the age of 50, compared to those in mainstream school settings. It is important to note here that the VSL usually runs its classes on Saturday mornings, and in some cases, after school on weeknights. This makes it an attractive option for teachers looking for part time teaching hours. Working on a Saturday morning may appeal to teachers approaching retirement age who are seeking more flexible working arrangements.

The demographic of the VSL staff that reveals perhaps the most remarkable picture, however, is the fact that only $16.1 \%$ of VSL survey respondents indicated that they were born in Australia. It is well known that among LOTE teachers in general, a significantly lower proportion are born in Australia, compared to those teaching in other fields. A 2010 survey reported that an estimated $71.8 \%$ of primary LOTE teachers and 52.6\% of secondary LOTE teachers across all educational sectors in Australia were Australian born (Weldon, Rowley, \& McKenzie, 2011, p. 64). It is these demographic figures in particular that reveal the extent to which the VSL teaching population is highly unique. This suggests that the VSL has a far greater proportion of overseas born staff than the proportion found among LOTE teaching staff in mainstream educational settings in Australia.

When interpreting these results, it is important to note that among the group of overseas born teachers, there will be great diversity. Many individuals will speak English as a native language, or speak English with near native level proficiency, while many will not. It is also important to note that many will speak more than one language and will be qualified to teach more than one language. Furthermore, it is also important to note that overseas born teachers at the VSL represent remarkable diversity in languages and cultures. It has been noted that “...although we commonly speak of 'languages education' ultimately languages are individual subjects, with particular profiles, histories, resources, purposes, images and other specificities which distinguish them from each other" (Lo Bianco and Slaughter, 2009, p. 46). The teaching population of the VSL encompass all of these individual subjects and their concomitant specificities, embodied under the umbrella of the one institution. This particular survey did not have the scope to investigate particular issues on a language by language basis, so for this reason, the survey results are limited to issues related to languages and their teachers in general.

The reasons for the VSL having such a high proportion of overseas born staff is complex. It has been suggested that the high level of language proficiency requirements for entry to LOTE teacher education courses in Australia has resulted in a higher proportion of native speakers flowing into the LOTE teaching population in general (Santoro, Reid and Kamler, 2001, p. 62). In the particularly unique case of the VSL, however, the unusually high proportion of overseas born teachers could also be related to the fact that the languages on offer at the VSL include a far broader range than those found in mainstream schools. For many overseas born teachers, it is possible that the language that they are qualified to teach may not be offered at mainstream schools. In fact one survey found that overseas born teachers in the Victorian government school system originated from some 40 countries but many of the languages spoken by this cohort were not taught in schools (Santoro, Reid and Kamler, 2001, p. 69-70).

Indeed, as the table below shows, In 2011, there were sixteen languages offered at primary and secondary government schools in Victoria (excluding the VSL). However the programs offered in 
Victorian mainstream schools tend to be concentrated around just six of the sixteen languages. The languages with the highest enrolments were Italian, Japanese, Indonesian, French, Chinese (Mandarin) and German (DEECD, 2012a, p. 11). This concentration among a small group of languages is not a recent development; as it was reported in 2006 (Lo Bianco and Slaughter, 2009, p. 40). As Table 4 illustrates, in 2011, for approximately 30 languages (highlighted in grey), the only Victorian government school that offered them at either primary or secondary level was the VSL. Because the range offered by the VSL is far broader, it is quite possible that the VSL has become a gathering place for overseas born teachers who are qualified to teach a broader range of languages than those offered in the mainstream system. Just as the VSL provides opportunities for students who cannot study the language of their choice at their day school, the same could be said for their teachers.

Table 4. Total enrolments in Languages study, government primary schools and secondary colleges, and the VSL, 2011

\begin{tabular}{|c|c|c|c|c|c|c|c|c|}
\hline Language & Primary & $\begin{array}{l}\text { Primary } \\
\text { VSL }\end{array}$ & $\begin{array}{l}\text { Primary } \\
\text { total }\end{array}$ & Second. & $\begin{array}{l}\text { Second. } \\
\text { VSL }\end{array}$ & $\begin{array}{l}\text { Second. } \\
\text { Total }\end{array}$ & $\begin{array}{l}\text { Total } \\
\text { Enrol. }\end{array}$ & $\%$ \\
\hline Italian & 53,114 & 198 & 53,312 & 19,105 & 468 & 19,573 & 72,885 & 24.3 \\
\hline Japanese & 38,108 & 80 & 38,188 & 17,602 & 767 & 18,369 & 56,557 & 18.9 \\
\hline Indonesian & 35,745 & 6 & 35,751 & 17,012 & 377 & 17,389 & 53,140 & 17.7 \\
\hline French & 18,562 & 103 & 18,665 & 19,630 & 622 & 20,252 & 38,917 & 13.0 \\
\hline $\begin{array}{l}\text { Chinese } \\
\text { (Mandarin) }\end{array}$ & 16,752 & 1,337 & 18,089 & 6,245 & 1,398 & 7,643 & 25,732 & 8.6 \\
\hline German & 11,653 & 40 & 11,693 & 10,836 & 452 & 11,288 & 22,981 & 7.7 \\
\hline Auslan & 11,017 & 0 & 11,017 & 813 & 0 & 813 & 11,830 & 3.9 \\
\hline Greek & 2,817 & 700 & 2,887 & 953 & 251 & 1,204 & 4,091 & 1.4 \\
\hline Spanish & 2,377 & 197 & 2,574 & 369 & 403 & 772 & 3,346 & 1.1 \\
\hline Vietnamese & 472 & 1,021 & 1,493 & 484 & 989 & 1,473 & 2,966 & 1.0 \\
\hline Turkish & 836 & 488 & 1,324 & 254 & 413 & 667 & 1,991 & 0.7 \\
\hline Arabic & 443 & 358 & 801 & 415 & 362 & 777 & 1,578 & 0.5 \\
\hline Karen & 940 & 164 & 1,104 & 0 & 121 & 121 & 1,225 & 0.4 \\
\hline Macedonian & 121 & 225 & 346 & 288 & 238 & 526 & 872 & 0.3 \\
\hline Sinhala & 0 & 339 & 339 & 0 & 176 & 176 & 515 & 0.2 \\
\hline Punjabi & 0 & 257 & 257 & 0 & 204 & 204 & 461 & 0.2 \\
\hline Korean & 133 & 102 & 235 & 0 & 216 & 216 & 451 & 0.2 \\
\hline Latin & 0 & 1 & 1 & 279 & 102 & 381 & 382 & 0.1 \\
\hline Croatian & 0 & 178 & 178 & 0 & 172 & 172 & 350 & 0.1 \\
\hline Hindi & 0 & 163 & 163 & 0 & 145 & 145 & 308 & 0.1 \\
\hline Dari & 0 & 121 & 121 & 0 & 136 & 136 & 257 & 0.1 \\
\hline Chin (Hakha) & 0 & 104 & 104 & 0 & 93 & 93 & 197 & 0.1 \\
\hline Polish & 0 & 29 & 29 & 0 & 162 & 162 & 191 & 0.1 \\
\hline Persian & 0 & 14 & 14 & 0 & 175 & 175 & 189 & 0.1 \\
\hline Bosnian & 0 & 61 & 61 & 0 & 108 & 108 & 169 & 0.1 \\
\hline Khmer & 0 & 82 & 82 & 0 & 83 & 83 & 165 & 0.1 \\
\hline Serbian & 0 & 43 & 43 & 0 & 60 & 60 & 103 & $<0.1$ \\
\hline Russian & 0 & 62 & 62 & 0 & 34 & 34 & 96 & $<0.1$ \\
\hline Hebrew & 0 & 42 & 42 & 0 & 47 & 47 & 89 & $<0.1$ \\
\hline Portuguese & 0 & 29 & 29 & 0 & 48 & 48 & 77 & $<0.1$ \\
\hline Dutch & 36 & 16 & 52 & 0 & 23 & 23 & 75 & $<0.1$ \\
\hline Classical Greek & 0 & 0 & 0 & 68 & 0 & 68 & 68 & $<0.1$ \\
\hline Albanian & 0 & 36 & 36 & 0 & 24 & 24 & 60 & $<0.1$ \\
\hline
\end{tabular}




\begin{tabular}{|l|l|l|l|l|l|l|l|l|}
\hline Filipino & 0 & 8 & 8 & 0 & 51 & 51 & 59 & $<0.1$ \\
\hline Maltese & 0 & 24 & 24 & 0 & 22 & 22 & 46 & $<0.1$ \\
\hline Hungarian & 0 & 15 & 15 & 0 & 19 & 19 & 34 & $<0.1$ \\
\hline Dinka & 0 & 14 & 14 & 0 & 15 & 15 & 29 & $<0.1$ \\
\hline Syriac & 0 & 20 & 20 & 0 & 7 & 7 & 27 & $<0.1$ \\
\hline $\begin{array}{l}\text { Aboriginal } \\
\text { languages }\end{array}$ & 0 & 0 & 0 & 23 & 0 & 23 & 23 & $<0.1$ \\
\hline Pushto & 0 & 9 & 9 & 0 & 10 & 10 & 19 & $<0.1$ \\
\hline Bengali & 0 & 15 & 15 & 0 & 3 & 3 & 18 & $<0.1$ \\
\hline Romanian & 0 & 3 & 3 & 0 & 15 & 15 & 18 & $<0.1$ \\
\hline Amharic & 0 & 16 & 16 & 0 & 1 & 1 & 17 & $<0.1$ \\
\hline $\begin{array}{l}\text { Chinese } \\
\text { (Cantonese) }\end{array}$ & 0 & 9 & 9 & 0 & 8 & 8 & 17 & $<0.1$ \\
\hline Tigrinya & 0 & 10 & 10 & 0 & 3 & 3 & 13 & $<0.1$ \\
\hline Swahili & 0 & 6 & 6 & 0 & 6 & 6 & 12 & $<0.1$ \\
\hline Bulgarian & 0 & 10 & 10 & 0 & 0 & 0 & 10 & $<0.1$ \\
\hline Lithuanian & 0 & 3 & 3 & 0 & 3 & 3 & 6 & $<0.1$ \\
\hline TOTAL & 192,496 & 6,758 & 199,254 & 94,376 & 9,032 & 103,408 & 302,662 & 100 \\
\hline
\end{tabular}

Source:DEECD 2012, Languages in Victorian Government Schools 2011, DEECD;Melbourne:p.11

\section{2. "Language teachers are given the recognition they deserve"}

It is not entirely clear why such a high number of overseas born language teachers are attracted to the VSL as an employer. Difficulties faced by language teachers in the mainstream are widely reported yet are complex. For example, many experience problems such as isolation, professional de-motivation, as well as "...difficulties in integrating language studies fully into curricula" (Sharpe, 2001, cited in Lo Bianco and Slaughter, 2009, p. 44). Furthermore, in the case of overseas born teachers, many do not feel supported in terms of resources, planning time and space allocation (Liddicoat et al. 2007, p. xi). Many report negative reactions in Australian classrooms to their cultural differences and more than half believe that racial discrimination exists in Australia (Collins and Reid, 2012, p. 58).

Some of the comments suggest that staff feel the VSL is a place where they do not experience some of the issues outlined above. Survey participants responded optimistically when an overwhelming $97.4 \%$ of respondents agreed with the statement, "The VSL is making a positive contribution to language learning". When they were asked to identify the strongest attribute of the VSL, 37.8\% of respondents selected "That it is good at what it does". Some survey respondents used the comments section of the VSL survey to explain in more detail. One staff member highlighted to the collegiality at the VSL, commenting: "I am proud to belong to such a dedicated team". Furthermore, VSL staff feel appreciated, thanks to the school's special focus on language learning, as one teacher commented: "The VSL is the only institution where language learning is the focus and teachers are given the recognition they deserve" (VSL survey).

\subsection{Multilingualism and multiculturalism}

Furthermore, the survey results suggest that the VSL is not the type of school where cultural differences prompt a negative reaction, as it can in mainstream school settings. Rather, the school is a place that is actively fostering the interests of the multicultural society of Victoria. Not surprisingly, when asked whether there was a place for ethnic community organisations in Victoria, an overwhelming 51.4\% of VSL survey respondents strongly agreed, and $42.0 \%$ agreed. Similarly, when asked whether they thought individuals are able to take pride in and maintain ethnic identities within Australia, 39.0\% of VSL 
survey respondents strongly agreed and 52.8\% agreed. Not surprisingly, when asked whether they thought Victoria is a multilingual society, an overwhelming $47.8 \%$ of VSL survey respondents strongly agreed and $45.0 \%$ agreed.

These results suggest that VSL staff are positive and optimistic about multilingualism and multiculturalism in Victoria. Accordingly, VSL survey respondents used the final section of the survey to voice their opinions. Their comments suggested that the school played a vital role in supporting these aspects of Victoria. As one teacher commented: "VSL program in languages is very important for the students from different nationalities... it affects the community positively... connecting different ethnic groups harmoniously" (VSL Survey, 2011). Another teacher added: "The VSL has the role to maintain the state of a multilingual society in which most people can speak more than one language" (VSL Survey 2011). As another participant added: "Australia is a Multicultural Nation; therefore, it must allow all people to learn their origin languages and cultures. [As] more languages [are] taught, more tolerance and peace are... VSL has contributed to enrich the cultures of Australia" (VSL Survey, 2011).

In some respects, it is not surprising that some staff in this responded in this way, especially considering that the cohort comprises such a high proportion of overseas born staff. Perhaps the comments of teachers in UK complementary school settings go some way towards explaining these responses. They see the teaching of their native language as important because it is "... an important means of reproducing their 'heritage' in the next generation" (Blackledge and Creese, 2008, p. 539).

\subsection{Teacher enthusiasm and dedication}

In terms of formal qualifications, the survey revealed that $44.3 \%$ of staff have a postgraduate level degree. The comments section of the survey also revealed that many of the teachers at the VSL are enthusiastic, passionate specialists. In fact these results echo another recent survey of language teachers that also found that they are "passionate about languages" (Absalom and Morgan, 2012, p. 36). It also goes some way towards satisfying the belief that "community languages need enthusiastic teachers" (ibid). Indeed, personal characteristics such as passion, dedication and enthusiasm have been identified as essential for accomplished language teachers (Kohler et al. 2006, p. 24).

As one VSL staff member commented: "The VSL is a fantastic school. A really good school with dedicated teachers to providing an enjoyable and valuable learning experience for language students" (VSL Survey, 2011). Other comments highlighted that some teachers have had a long term relationship with the school and a long term commitment to the language teaching field. "I graduated from VSL (Saturday School) Japanese and Spanish, studied them in Uni as Majors - and now teach French for students who wish to further their language study" (VSL Survey, 2011). Another commented: "I have been working for the VSL for 25 years at various centres as a language teacher Prep-12" (VSL Survey, 2011). Several respondents also indicated that they teach a language at the VSL as well as in a mainstream school during the week: "My day-school students wish to study Korean etc and I am proud to be able to offer the services of the VSL, [in] both school centres and Distance Education programs" (VSL Survey, 2011).

\subsection{VSL staff views about attitudes towards language learning}

The survey revealed that the VSL staff are highly attuned to current issues affecting language provision in Australia. In particular, staff expressed concern about the negative attitudes towards language learning in Australian society. An overwhelming $84.5 \%$ of respondents agreed that there is a lack of understanding of the benefits gained from learning languages at schools as well as the in the wider community. There are "A myriad of reports on foreign language education has endorsed the many social, cultural, economic, 
cognitive and personal benefits that can flow from learning a second language" (Group of Eight, 2008, p. 1). Yet studies show that many problems contribute to an indifference towards language study in Australian society in general. These include low levels of student motivation, lack of employment prospects, a lack of support and resources in schools, and a low status of languages in general (Kipp, Clyne and Pauwels, 1995, p. 150). Other problems include a general perception among school students with an English speaking background that language study is not worth the effort, that there are easier subjects available, and that English is the dominant language anyway (Smolicz and Secombe, 2003, p. 16). The devaluation of learning languages in the workforce is explained by Schanzer as follows: "Despite the value placed on the study of foreign languages by many educators, few Australians from Englishspeaking backgrounds ever master a foreign language and most Australian business and government departments do little to encourage foreign language skills as the route to a successful career" (cited in Kearney, 1999, p. 9).

This point resonated with VSL staff, as several participants used the comments section at the end of the survey to elaborate further: "I am worried that Australians in general do not acknowledge a need to learn foreign languages" (VSL survey). Another sounded almost exasperated at the lack of understanding of the value of language learning in this country: "The majority of the world valued and still values languages. Why is it taking Australia so long to follow the world standards? Are we really so narrow minded that English is enough? Time we stepped forward and kept pace with the rest of the world" (VSL survey).

Stemming from the problem of widespread indifference towards language learning is the issue of student motivation for language learning. Survey results suggest that this is another area of concern for VSL staff. $62 \%$ of respondents agreed with the statement that "There is a sense of doubt among students regarding the usefulness of learning a language". Participants were then asked to indicate the most important reason why students choose language study. 38.2\% indicated that the most important reason why students choose to study languages is because they think learning languages is useful and valuable. However a large proportion also cited practical reasons, with $25.9 \%$ indicating that students study languages because it brings bonus points for future studies. This was closely followed by $24.8 \%$ of respondents who indicated that that students study languages because parents insist. On the other hand, when asked to indicate the least important reason why students choose to study languages, $27.2 \%$ of respondents selected its being obligatory. This was followed by $22.1 \%$ of participants indicating that one of the least important reasons for students' choosing to do languages is because of their peers.

These results suggest that VSL teachers believe that their students choose language study for the right reasons. Students favour language study because it is useful and valuable, not because it is compulsory or because of peer pressure. In fact scholars have explained that the question of whether language study is compulsory or elective is highly contentious, to the point that "The mandating of languages is probably the most controversial of the policy issues around language study" (Liddicoat et al. 2007, p. 20). The VSL is a special case which is exempt from this debate, however, as language programs at the VSL are entirely elective since they run out of school hours, and students therefore make a considerable sacrifice to give up their free time to commit to classes. However VSL students are hardly exempt from parental obligation. A quarter (24.8\%) of VSL survey participants indicated that they believe students choose language study because their parents insist. This is a point that resonated with one respondent, who in fact emphasised the positive role that parents play in their child's decision making: "I feel the need to study languages comes primarily from the parent. As each new generation becomes more entrenched in the Australian way of life the need to keep ties to the old country and culture are significantly reduced" (VSL survey).

A quarter of survey participants (25.9\%) also indicated that they believe students choose language study because of the 'bonus points' they gain at VCE level. The bonus system was introduced in Victoria 1994 in by the Victorian Vice Chancellors' Committee as a strategy to boost the number of students 
continuing their language studies until the end of senior high school (Elder, 2000, p. 102). Despite this initiative, scholars remain concerned about the low number of enrolments at VCE level, as they still continue to fall short of targets (Willoughby, 2006, p. 4).

This touches on another issue that was explored in the survey - that of the decline in interest among background speakers of languages. 59\% of survey respondents agreed with the statement that "Students are losing interest in their heritage/ethnic language and culture". Generalising across the broad range of languages represented at the VSL can be onerous. While the VSL delivers programs for a large number of languages with high proportions of students with heritage background in the language, and with varying degrees of background proficiency in the language. However, the same cannot be said for all languages taught at the VSL, as it does also deliver programs in a small number of languages with a proportion of students who are beginners and do not have a background in the language. However, because the VSL specialises in languages that are usually not catered for in the mainstream education system, heritage languages are generally seen as the school's "bread and butter". Not surprisingly, staff expressed concern about protecting this area: "... some of the languages of the minority groups will definitely fade away ... VSL can do very little without them" (VSL survey).

Furthermore, examining student motivation for heritage language study is a complex task that encompasses factors such as language shift as well as issues of identity. Scholars in Australia have examined census data to identify particular language groups that are ageing and therefore considered to have declining levels of use in society (Clyne and Kipp, 2002, p. 34). Linguists have documented reasons why some speakers of heritage languages are reluctant to pursue study in their language. These include a preference for their children study languages that are deemed to be of greater international importance than their own heritage language, as they believe it will be more useful in their careers (Willoughby, 2006, p. 9). It has also been stated that some students are content to simply have an acceptable enough level of proficiency that will enable them to socialise with family and friends; "As long as the other person understands you" (Willoughby, 2006, p. 10). Therefore it is not surprising that staff made comments to emphasise the view that the VSL plays a key role in maintaining heritage languages for Victorian students: "VSL has a vital role to promote and maintain the community languages now and in the future" (VSL survey). Furthermore, comments reveal that VSL staff see the school's role as going beyond language maintenance for individual groups; rather it is playing a key role in maintaining the multicultural nature of the broader society: "The VSL, as a government school has an important role in the maintenance and development of languages and it manifests the Government's commitment to and support of multiculturalism" (VSL survey).

\subsection{Staff views about a label for languages as a curriculum area}

When VSL staff members were asked which of the given terms they believe best defines the curriculum area of non-English languages, staff indicated a broad range of views. By far, the majority of respondents indicated that the term "Languages Other Than English (LOTE)" (68.4\%) defines the curriculum area the best. This was followed by a smaller proportion that prefers the term "Languages" (12.5\%). Even fewer staff prefer the terms "Community Languages" (9.1\%), "Foreign Languages" (4.5\%) "Ethnic Languages" (3.6\%), and "Migrant Languages" (1.9\%).

This confusion is a symptom of the long standing debate in Australia about the appropriate label to use for non-English languages as a curriculum area. The history of languages education in Australia has long been characterised by many shifts in the ways that languages have been labelled. "These include 'classical', 'modern', 'foreign', 'migrant', 'ethnic', 'community', 'languages other than English', 'languages', 'Asian' or 'European', and 'geopolitical'. There have also been significant shifts in the labels used to identify those languages that are indigenous to Australia, from 'Aboriginal' to 'Australian 
Indigenous Languages', and more recently to 'Australian Languages"” (Mercurio and Scarino, 2005, p. 146). These labels have served particular purposes in different contexts. They have acted as tools of reference and indicate whether certain languages should be included or excluded. As policies have shifted over time, so have the labels, reflecting the dominant beliefs about language education (ibid).

$9.1 \%$ of VSL staff still believe that the term 'community languages' best defines their field. From the mid-1970s in Australia, this term was used to denote languages spoken among migrant communities. For a time, it was considered ideal because it replaced terms such as "foreign languages", "migrant languages" and "ethnic languages" which were deemed discriminatory and inadequate (Clyne, 1991, p. 3). In addition, it legitimised the continuing existence of all languages in Australia (ibid). However, writers challenged this term, arguing that it is too broad and unclear which particular community is being referred to. In the North American context, the label "heritage languages" is accepted (Mercurio and Scarino, 2005 , p. 146). Linguists recognise that both the terms "heritage languages" and "community languages" have their limitations (Hornberger, 2005, p. 102).

In educational settings, the term "Languages Other Than English" (LOTE) was used in Australia for many years. However in a Commonwealth government statement on languages education that was issued for the period 2005-2008, the term "LOTE" was replaced with the simple "languages" (Liddicoat et al. 2007, p. 3). This change was confirmed in March 2012, when the Victorian Department of Education and Early Childhood announced that the term "LOTE" would be replaced by the term "languages" (DEECD memo, 2012). By replacing the label "LOTE" with "languages", the emphasis on English as the dominant language has been eliminated. The term "languages" enables languages to stand alone in their own right; they no longer need to be qualified by their relationship to English.

While these frequent changes have enabled the languages area to be updated and brought into line with current ideologies, it has clearly brought confusion. These survey results suggest that as a consequence of these shifting terms, many teachers working at the chalkface are still quite unclear about the name that best represents their subject area. The fact that some teachers still identify most strongly with discriminatory and outdated labels for their subject area can be seen as a legacy of these constantly shifting agendas. Despite this, the largest proportion of VSL staff clearly indicated that they still favour the term LOTE and still use the term as the label that best describes the study of languages. Indeed, in the comments section of the survey, there were 47 instances where VSL staff used the term LOTE to express their opinions about this particular curriculum area.

\section{Conclusion}

The VSL, which has been called "unique in its origins and accidental in its role" (Mascitelli \& Merlino, 2011) has had a particularly crucial role in the field of language delivery in the state of Victoria since 1935. This study provided a snapshot of the responses of its protagonists and their inside view of the instrument they treasure most: languages. This unique group, which represents a rich concentration of cultural and linguistic heritage, and a specialist working environment that is dedicated to language learning, can be seen as a beacon for others working in broader educational settings. Their deep concerns about problems affecting the languages education field should be seen as a warning to policy makers and governments, not just in Victoria, but in Australia and abroad. VSL staff are worried about the lack of understanding of the benefits gained from learning languages at schools as well as the in the wider community, and the resulting general lack of interest among students. They are also confused about the best label to define their subject area, which can be seen as a symptom of the frequent "chopping and changing" of the languages area over the decades. This paper argues that for the languages education area to move forward, significant changes need to be made to increase the level of advocacy for the languages 
area. Australians need to understand that English is no longer enough; they need to appreciate that language learning has important benefits for individuals and for the society. Despite these concerns, the VSL staff are overwhelmingly positive about the critical role that this institution plays in language delivery and in fostering the levels of multilingualism and multiculturalism in Victoria. Due to limitations of space, the issues presented here represent only a selection of the topics explored in the survey. Indeed, the survey did reveal that many teachers expressed concerns about a range of areas that could be improved in the provision of languages at the VSL, and it is intended that those issues will be the subject of a separate paper.

\section{References}

Australian Bureau of Statistics, (2013). Australian census of population and housing 2011. Available at: http://www.abs.gov.au/websitedbs/censushome.nsf/home/data?opendocument\#from-banner=LN, accessed: 30 May 2013.

Absalom, M., \& Morgan, A. (2012). What language teachers want: Considering the evaluation of 18th biennial conference. Babel, 47(1), 32 - 38.

Blackledge, A., \& Creese, A. (2008). Contesting 'language' as 'heritage': negotiation of identities in late modernity. Applied Linguistics, 29(4), 533-554.

Brown, S. (2008). Multicultural society, monocultural media: SBS-more special than ever. The Sydney Paper, 20(4), i.

Carsaniga, G. (1994). To be or not to be: Australian 'community languages' or 'Australian community' languages: an Italo/ Australian viewpoint. Babel, 29(3), 4-7.

Clyne, M. (1991). Community languages: The Australian experience, UK: Cambridge University Press.

Clyne, M. (2005). Australia's language potential, Sydney: University of New South Wales Press.

Clyne, M. (2006). Empowerment through the community language - a challenge. In M. Pütz, J.A. Fishman and J. Neff-Van Aertselaer (Eds.), Along the routes to power: Explorations of empowerment through language (pp. 107-126). New York: Mouton de Gruyter.

Clyne, M. (2007). Are we making a difference? On the social responsibilities and impact of the linguist/applied linguist in Australia. Australian Review of Applied Linguistics, 30(1), Australia: Monash University.

Clyne, M. (2011). Three is too many in Australia. In C. Hélot and M. Ó. Laoire (Eds.), Language policy for the multilingual classroom: Pedagogy of the possible (pp. 174-187). UK: Multilingual Matters, Bristol.

Clyne, M., \& Fernandez, S. (2008). Community language learning in Australia. Encyclopedia of language and education, 4 , 169-81.

Clyne, M., Fernandez, S., \& Grey, F. (2004). Languages taken at school and languages spoken in the home: a comparative perspective. Australian Review of Applied Linguistics, 27(2), 1-17.

Clyne, M., \& Kipp, S. (2002). Australia's changing language demography. People and Place, 10(3), 2935.

Collins, J., \& Reid, C. (2012). Immigrant teachers in Australia. Cosmopolitan Civil Societies Journal, $4(2), 38-61$.

Crawford, J. (1995). School language learning: where are we really going?. Babel, 30(1), 20-30. 
Creese, A. (2009). Building on young people's linguistic and cultural continuity: Complementary schools in the United Kingdom. Theory Into Practice, 48(4), 267-273.

DEECD, (2012a). Languages in Victorian Government schools 2011. DEECD; Melbourne.

DEECD, (2012b). 2010 - 2011 teacher supply and demand report for the Victorian teacher supply and demand reference group. DEECD; Melbourne.

Elder, C. (2000). Outing the native speaker: The problem of diverse learner backgrounds in 'foreign' language classrooms - an Australian case study. Language, Culture and Curriculum, 13(1), 86-108.

Extra, G. (2007). From minority programmes to multilingual education. In P. Auer and L. Wei (Eds.), Handbook of Multilingualism and Multilingual Communication (pp. 175-206). Walter de Gruyter, Inc.

Group of Eight, (2008). Languages in crisis: a rescue plan for Australia, Group of Eight Manuka, A.C.T.

Guest, D. (2012). Title of memo: S086-2012 change of nomenclature from LOTE to languages and ESL to English as an additional language (EAL), Victoria: Department of Education and early Childhood Development.

Hornberger, N.H. (2005). Heritage/community language education: US and Australian perspectives. International Journal of Bilingual Education and Bilingualism, 8(2-3), 101-108.

Kearney, G. (1999). Language before linguistics? The cart before the horse. Babel, 34(1), 10-15,37.

Kipp, S., Clyne, M., \& Pauwels, A. (1995). Immigration and Australia's language resources. Canberra: Australian Government Publishing Service.

Kohler, M., Harbon, L., Fischmann, V., McLaughlin, M., \& Liddicoat, A.J. (2006). Quality teaching: Views from the profession. Babel, 40(3), 23-38.

Leuner, B. (2010). Patterns of language use: Polish migrants from the 1980s and their children in Melbourne. Babel, 44(3), 27-37.

Liddicoat, A.J., Scarino, A., Jowan Curnow, T., Kohler, M., Scrimgeour, A., \& Morgan, A-M. (2007). An investigation of the state and nature of languages in Australian schools: Prepared by the research centre for languages and cultures education university of South Australia. Dept. of Education, Employment and Workplace Relations, Canberra: A.C.T.

Lo Bianco, J., Slaughter, Y., \& Australian Council for Educational Research, (2009). Second languages and Australian schooling, ACER, Camberwell, Vic.

Mascitelli, B., \& Merlino, F. (2011). By accident or design? The origins of the Victorian School of Languages. Babel, 46(2-3), 40-47.

Mercurio, A., \& Scarino, A. (2005). Heritage Languages at upper secondary level in South Australia: A struggle for legitimacy. International Journal of Bilingual Education and Bilingualism, 8(2-3), 145159.

Ozolins, U. (1993). The politics of language in Australia. Cambridge [England]: Cambridge University Press.

Santoro, N., Reid, J., \& Kamler, B. (2001). Making difference count: A demographic study of overseas born teachers. Australian Journal of Education, 45(1), 62-75.

Smolicz, J. (1997). Australia: from migrant country to multicultural nation. International Migration Review, 31(1), 171-186. 
Smolicz, J.J., \& Secombe, M.J., (2003). Assimilation or pluralism? Changing policies for minority languages education in Australia. Language Policy, 2(1), 3-25.

VSL Survey, (2011). Undertaken by H. Avara, Victorian School of Languages, Melbourne

Weldon, P., Rowley, G., \& McKenzie, P. (2011). Profiles of teachers in selected curriculum areas: Further analyses of the staff in Australia's schools 2010 survey.

Willoughby, L., (2006). Heritage LOTEs at VCE level: student perspectives on current programs. Monash University Linguistics Papers, 5(1), 3-15.

Year Book Australia, (2008). http://www.abs.gov.au/ausstats/abs

@.nsf/0/636F496B2B943F12CA2573D200109DA9?opendocument, Accessed: 10 February 2012

\section{Çokkültürlü bir ortamda dil öğretimi: Viktorya diller okulunun özgün dil öğretmenleri topluluğunun görüşleri}

\section{$\ddot{O ̈ z}$}

Victoria Eyaleti, Avustralya'da en fazla etnik çeşitliliğe ve evde kullanılan en fazla ikinci dile sahiptir. Ayrıca okullarda dil öğrenimine katılan en yüksek öğrenci oranına sahiptir. Viktorya, aynı zamanda, ülkenin dil öğretimi alanında en büyük ve en eski devlet okulu olan Viktorya Diller Okulu'na da ev sahipliği yapmaktadır. Viktorya Diller Okulu (VSL), eyalet genelinde 40'ın üstünde merkezde yaklaşık 16.000 öğrenciye, 45 'in üstünde farklı dilde eğitim vermektedir. Bu makale VSL'deki dil öğretmenlerinin şimdiye kadar ele alınmamış olan görüşlerini araştırmaktadır. Araştırma, 552'den fazla yanıtla, VSL personelinin (çoğunlukla öğretmenler) kapsamlı bir anonim anketine dayanmaktadır. Sonuçlar, hem öngörülebilir, hem de çeşitlidir. Bulgular, VSL'deki personelin, Avustralya'daki diğer herhangi bir kurumda karşılaşılmayan, kültürel ve dilsel çeşitlilik açısından çok zengin bir topluluğu temsil ettiği için, demografik olarak benzersiz bir grup olduğunu göstermektedir. Bu makale, dil öğretimini gururla "esas işi” olarak benimseyen, özel bir ortamda çalışan bu istisnai grubun görüşlerini sunmaktadır. Anket, personelin oldukça hevesli olduğunu ve okullarının Viktorya eyaletinde çokdilliliği ve çokkültürlülüğü beslemede oynadığı role güçlü bir şekilde inandığını ortaya koymuştur. Ancak, araştırma aynı zamanda, katılımcıların, Avustralya'da dil eğitimi alanındaki bazı güncel sorunlar hakkında derin endișelerini de ortaya çıkarmıştır. Bunlara ek olarak, şu anda bir müfredat alanı olarak 'diller' için en iyi tanımlama üzerinde bir görüş ayrılığı olduğunu ortaya koymuştur. Bu makale, bu uzman kurumdaki personelin düşüncelerinin oldukça oturmuş olduğunu, bu nedenle Avustralya ve denizaşırı ülkelerdeki diğer eğitim ortamlarında dil eğitimi alanındaki profesyonellerin endişeleri için bir işaret olarak görülebileceğini savunmaktadır.

Anahtar sözcükler: yabancı dil eğitimi; Viktorya Diller Okulu (VSL); Avustralya; çokkültürlülük; çokdillilik

\section{AUTHOR BIODATA}

Hayriye Avara taught at Hacettepe University, School of Foreign Languages from July 1998 to February 2020. She was a researcher at Ca' Foscari, University of Venice from September 2005 to August 2006. She worked as a Turkish language advisor in Australia with the Victorian School of Languages in Melbourne from February 2010 to December 2014. She taught at Ca' Foscari, University of Venice, Department of Asian and North African Studies from October 2017 to September 2018. She started teaching at Amasya University, Department of English Language 
Teaching in February 2020. Her research interests include language teaching, literature, ethnic experiences, gender, multilingualism and multiculturalism.

Bruno Mascitelli is an Adjunct Professor at Swinburne University of Technology. He was Victorian School of Languages School Council President from 2005 until 2017. He researches in the area of European culture, politics and political economy and was a Jean Monnet Chair from 2016-2019.

Catherine Bryant completed her PhD in 2016 at Swinburne University in Victoria, Australia. Her thesis was titled "From "special experiment" to state specialist language school: The Victorian School of Languages 1935-2015". Catherine has a background in the teaching of Japanese and history in secondary schools. She works in the Languages Unit at the Victorian Curriculum and Assessment Authority in Victoria, Australia. 